\title{
REPRODUCTIVITY, PRODUCTIVITY AND MANAGEMENT SYSTEM OF INDIGENOUS BUFFALO (Bubalus bubalis) COWS IN COSTAL AREAS OF PIROJPUR AND BORGUNA DISTRICT OF BANGLADESH
}

\author{
M. R. Karim, M. Z. Hossain ${ }^{1}$, M. R. Islam², M. S. Parvin ${ }^{3}$ and M. A. Matin ${ }^{4}$ \\ Faculty of Animal Science and Veterinary Medicine, Patuakhali Science and Technology \\ University, Khanpura, Babugonj, Barisal-8210, Bangladesh
}

\begin{abstract}
Twenty five buffalo cows of Mothbaria Upazila of Pirojpur district and another twenty five indigenous buffalo cows of Pathorghata Upazila of Borguna district of Bangladesh were randomly selected and interviewed to collect data on reproductivity (gestation length, birth weight, age of first calving, post partum heat and calving interval), productivity (lactation length and daily milk yield) and management system (general management, housing, feeding, calf rearing and treatment facilities) of indigenous buffalo cows using pre-tested questionnaire during the period from January to June 2010. The reproductive parameters including gestation length, birth weight, age of first calving, post partum heat and calving interval of Mothbaria Upazila of Pirojpur district were $319.56 \pm 5.93$ days, $24.28 \pm 4$ kilograms, $50.88 \pm 1.71$ months, $153.6 \pm 6.13$ days, $547.92 \pm 10.88$ days respectively whereas in case of Pathorghata Upazila of Borguna district these parameters were $319.12 \pm 4.69$ days, $24.12 \pm 3.6$ kilograms, $51 \pm 1.8$ months, $153.44 \pm$ 6.78 days, $547.24 \pm 14.32$ days respectively. The productive parameters including lactation length and daily milk yield of Mothbaria Upazila of Pirojpur district were $286.12 \pm 11.27$ days and $3.33 \pm 0.68$ liters/day respectively while in case of Pathorghata Upazila of Borguna district these parameters $290.44 \pm 10.92$ days and $3.43 \pm 0.744$ liters/day respectively. So, reproduction and production are almost regular comparing with other published reports with the exception of age of first calving which is almost 12 months later than the buffaloes of other countries. It could be concluded that the buffalo owners of these areas do not follow any scientific method of buffalo husbandry; they just follow traditional rearing system. The farmers mostly use buffaloes for draught purpose in these costal areas.
\end{abstract}

Key Words: Buffalo, Reproductivity, Productivity, Management, Costal areas

\section{INTRODUCTION}

The domestic buffalo is an important animal in the agricultural economy of many tropical and subtropical countries (Suhail et al., 2009). Buffalo, also known as 'Asian Animal' plays

\footnotetext{
1Department of Physiology, 2Department of Surgery and Obstetrics, 3Department of Medicine, Bangladesh Agricultural University, Mymensingh-2202, Bangladesh

4Department of Dairy and Poultry Science, Patuakhali Science and Technology University, Khanpura, Babugonj, Barisal-8210, Bangladesh

*Corresponding author (Email: matinma2000@yahoo.com)
} 
very important role in agricultural economy, being an integral part of farming system. Buffalo is contributing $12.1 \%$ to the world, $38.0 \%$ in Asia, $66.6 \%$ in Pakistan, $55.0 \%$ in India, $16.4 \%$ in China, $50.8 \%$ in Egypt and $65.2 \%$ in Nepal's total milk production (FAO, STAT, 2007). In addition to the milk buffalo is also used as an important source of beef production in the form of culled adult females, males and unwanted male calves. Buffalo is contributing around $1.3,2.8,24.4,26.9,0.6,21.2$, and $51.8 \%$ of the total meat production in the aforementioned countries (Suhail et al., 2009). Its service to the people of most of these countries with regards to the supply of milk, meat and draught power is far greater than any other domestic animal. The productive/reproductive traits in dairy animals are influenced by several genetic and environmental factors. Any breed development programme would be based on the exploitations of the genetic variation. It is a well known fact that milk production increases with age at an ever till maximum production is attained and decreases later on. Khan et al. (2008) investigated the post-conception decline in milk yield and reported that dairy buffaloes in parity 3 had the least reduction in milk yield followed by parity 2, 4, 1, 5, and 6, indicating parity 3 as the best phase for milk production in dairy buffaloes. The reduction in milk was smallest in summer followed by winter, spring and autumn. Bashir et al. (2007) reported that economic returns from dairy buffaloes depend on lifetime performance. Herd life and productive life were also used to describe lifetime performance. Husbandry and production systems for buffaloes vary depending on the topography and vegetation patterns of the country. Buffaloes are raised under an extensive system in the coastal and hilly areas where large-scale pasture land and enough green forage are available. There are several published reports regarding reproductive and productive parameters and management system of buffalo cows throughout the world (Hadi, 1965; EI-Kirabi, 1995 and Suhail et al., 2009) but there is very limited information of this issue in contest of Bangladesh especially in costal areas (Faruque et al., 1990, 1995). Considering the fact this investigation was performed in two costal districts of Bangladesh namely Pirojpur and Borguna to study reproductive and production parameters and management system of buffalo cows.

\section{MATERIALS AND METHODS}

To conduct the study two costal districts of Bangladesh namely Pirojpur and Borguna were selected. Twenty five buffalo cows of Mothbaria Upazila of Pirojpur district and another 25 buffalo cow of Pathorghata Upazila of Borguna district of Bangladesh were randomly selected to collect data regarding reproductive and productive performance of those buffalo cows with separate questionnaires during the period from January to June 2010. Gestation length, birth weight, age of first calving, post partum heat and calving interval were recorded as the reproductive parameters. Lactation length and daily milk yield were recorded as the productive parameters. Housing, feeding, calf rearing and treatment facilities were recorded as the management variables. All collected data were analyzed by Statistical Package for Social Sciences (SPSS 17.0) software to have mean and standard deviation (SD). 


\section{RESULTS AND DISCUSSION}

\section{Reproductivity}

\section{Gestation length}

The average gestation period of indigenous buffalo cows of Mathbaria Upazila under Pirojpur district of Bangladesh is $319.56 \pm 5.93$ days while the average gestation period of Patharghata Upazila under Barguna district of Bangladesh is $319.12 \pm 4.69$ days (Table 1). Hadi (1965) reported an average gestation period of Marathwada buffalo as $309.60 \pm 2.11$ days. The average gestation period of Egyptian buffalo as $316.70 \pm 0.19$ days (EI-Sheikh and Mohammed, 1967). The average gestation length in Indian buffalo cows as $308 \pm 9.6$ days (Joshi et al., 1968). So, the findings of the present study were similar to the findings of various authors as mentioned above.

Table 1. Reproductive parameters of buffalo cows in Mothbaria Upazila of Pirojpur district and Pathorghata Upazila of Borguna district of Bangladesh

\begin{tabular}{cll|c}
\hline Sl. No. & \multicolumn{1}{c|}{ Parameters } & Mothbaria (Pirojpur) & Pathorghata (Borguna) \\
\hline 1. & Gestation length (days) & $319.56 \pm 5.93$ & $319.12 \pm 4.69$ \\
2. & Birth weight (kg) & $24.28 \pm 4$ & $24.12 \pm 3.6$ \\
3. & Age of first calving (months) & $50.88 \pm 1.71$ & $51 \pm 1.8$ \\
4. & Post partum heat (days) & $153.6 \pm 6.13$ & $153.44 \pm 6.78$ \\
5. & Calving interval (days) & $547.92 \pm 10.88$ & $547.24 \pm 14.32$ \\
\hline
\end{tabular}

The above values represent the mean \pm standard deviation (SD) of different reproductive parameters which were obtained by interviewing buffalo owners $(n=25)$

\section{Birth weight}

The average birth weight of indigenous buffalo calves are $24.28 \pm 4.00$ and $24.12 \pm 3.60$ kilograms in Mothbaria Upazila of Pirojpur and Pathorghata Upazila of Borguna district, respectively (Table 1). The birth weight of indigenous buffalo calves were similar to the findings of Chantalakhana et al. (1984) who reported that the average birth weight of swamp male and female calves as 28.60 and 26.97 kilograms, respectively in Thailand. Faruque and Amin (1995) reported the average birth weight of indigenous buffaloes of the coastal areas of Bangladesh as $22.00 \pm 3.50$ kilograms which was also similar to the findings of the present study.

\section{Age at first calving}

The age at first calving of indigenous buffaloes of Mothbaria Upazila of Pirojpur and Pathorghata Upazila of Borguna district of Bangladesh are 50.88 \pm 1.71 months and $51.00 \pm$ 1.80 months, respectively (Table 1). The reported age at first calving in buffalo varied from 36-48 months (Fadzil, 1969; Cuong, 1983 and Shah et al., 1987). So, it could be stated that age of first calving in indigenous buffalo calves of Bangladesh is almost 12 months later than the buffaloes of other countries. 


\section{Post partum heat interval}

The average post partum heat interval of indigenous buffalo cows in Mothbaria Upazila of Pirojpur and Pathorghata Upazila of Borguna district of Bangladesh are $156.30 \pm 6.13$ days and $156.44 \pm 6.78$ days, respectively (Table 1 ). The range of reported post-partum heat interval varied from 30-171 days (Fadzil, 1969; Rao et al., 1973; Janakiraman, 1982; Liu et al., 1985; Parvez et al., 1994 and Tailor et al., 1997). Our findings have similarly with the upper range of reported post-partum heat interval.

\section{Calving interval}

The average of calving interval of indigenous buffalo of that studied areas are $547.92 \pm 10.88$ days and 547.24 \pm 14.32 days of Mothbaria Upazila of Pirojpur and Pathorghata Upazila of Borguna district, respectively (Table 1). The findings of the present study were similar to the findings of EI-Sheikh and Mohammed (1967) who found that first calving interval of Egyptian buffalo was $484.74 \pm 2.86$ days. Fadzil (1969) carried out an experiment on Swamp buffalo in Malaysia under village condition and found that calving interval was 639 days. Parera et al. (1987) found that average calving interval of indigenous buffaloes in Srilanka was $384.9 \pm 62.9$ days. The calving interval ranged from 329 to 816 days. The findings of present study were almost similar.

\section{Productivity}

\section{Lactation length}

The average lactation length of indigenous buffalo cows are $286.12 \pm 11.27$ days and $290.44 \pm$ 10.92 days respectively, in Mathbaria and Pathorghata Upazila under Barguna district of Bangladesh (Table 2). The findings of this study are more or less similar to the findings of other authors (Faruque et al., 1990; Faruque and Amin, 1995 and EI-Kirabi, 1995).

\section{Daily milk yield}

The average milk yield of indigenous buffalo under Barguna district is $3.43 \pm 0.744$ liters (Table 2). On the other hand, the average daily milk yield of indigenous buffalo at Mathbaria Upazila under Pirojpur district is $3.33 \pm 0.68$ liters (Table 2). Similar findings were also reported by other authors (Faruque et al., 1990 and Shabede et al., 2003).

\section{Management System \\ General management}

The farmers of the study areas rear buffaloes mainly for draught purpose but also for milk production. Averagely they rear 3-4 buffaloes. The floor of the yard is rough and muddy. The herd size varied from 3-4 buffalos.

\section{Housing}

Loose housing system is generally practiced. Most of the farmers don't have well idea about group wise housing. The house normally cleaned once a day. No disinfectant is used cleaning the sheds. No separate maternity stalls are also available. All the farmers use cow dung for the production of bio-fertilizer. 
Table 2. Productive parameters of indigenous buffalo calves under Mothbaria Upazila of Pirojpur district and Pathorghata Upazila of Borguna district of Bangladesh

\begin{tabular}{c|c|c|c}
\hline Sl. No. & \multicolumn{1}{c}{ Parameters } & Mothbaria (Pirojpur) & Pathorghata (Borguna) \\
\hline 1. & Lactation length (days) & $286.12 \pm 11.27$ & $290.44 \pm 10.92$ \\
2. & Daily milk yield (liter) & $3.33 \pm 0.68$ & $3.43 \pm 0.744$ \\
\hline
\end{tabular}

The above values represent the mean \pm standard deviation (SD) of different reproductive parameters which were obtained by interviewing buffalo owners $(n=25)$

\section{Feeding}

Buffaloes are allowed to grazing whole day long, when there is no crop in the field. Sometimes stall feeding (straw only) is practiced before entering the cow sheds. Group-wise feeding is not practiced.

\section{Calf rearing}

All farmers of studied area provide colostrums to the calves for feeding. Bottle feeding and Milk replacer are not used. Housing of the calf arranged with herd. Fifteen-twenty five calf mortality was reported by the farmers.

\section{Treatment facilities}

Veterinary support or government steps for the improvement of the buffalo population of studied are not sufficient. Mostly around the Upazila, the governmental initiatives are found, but not to periphery of that Upazila. Herd deworming are not regularly practiced here. Most of the farmers perform deworming to the buffaloes occasionally.

\section{CONCLUSION}

It could be concluded that the owners of buffaloes of the costal areas of Bangladesh do not rear their buffaloes in a scientific way rather than following traditional ways. The reproductivity and productivity are almost regular comparing with other published reports with the exception of age of first calving which is almost 12 months later than the buffaloes of other countries. It is needed to improve the productive and reproductive performance of indigenous buffalo cows in order to gain more profit from buffalo rearing. Prospective cohort study should be performed to have precise information on reproductive and productive parameters of indigenous buffalo calves of Bangladesh.

\section{RFERENCES}

Bashir, M. K., Khan, M. S., Bhatti, S. A. and Iqbal, A. 2007. Lifetime performance of Nili-Ravi buffaloes in Pakistan. Asian-Aust. J. Anim. Sci., 20(5): 661-668.

Chantalakhana, C., Bunyavejchewin, P., Faarungsrng, S. and Kamnerdpetch, V. 1984. Estimates of Heritability and relationships between body weight, weight gains and measurements of the swamp buffalo. Buffalo Bulletin, 3(1): 3-5. 
Cuong, L. X. 1983. Performance of Vietnamese swamp buffaloes. Buffalo Bulletin, 2(1): 12-13.

EI-Azab, E. A. 1974. Effect of gestation on post-partum period in buffaloes. J. Egyptian Vet. Med. Assoc., 54: 631-639.

EI-Kirabi, E. 1995. Buffalo population and production in Egypt. Buffalo Newsletter, 3: 8.

EI-Sheikh, A. S. and Mohammed, A. A. 1967. The reproductive performance of the Egyptian buffalo. J. Animal Prod., 5: 99-117.

Fadzil, M. 1969. A study on the calving frequency and age at the time of calving of Malaysian swamp buffaloes. The Malaysian Agricultural Journal, 47(2): 203-206.

FAO. STAT. 2007. Statistical Division, Food and Agriculture Organization, UNO, Rome, Italy.

Faruque, M. O. and Amin, M. R. 1995. Indigenous buffaloes in the coastal area of Bangladesh: part-II. Productivity of indigenous buffaloes in the south western coastal area. Bangl. J. Train. Develop., 4: 138-140.

Faruque, M. O., Hasnath, M. A. and Siddique, N. U. 1990. Present status of buffaloes and their productivity in Bangladesh. Asian-Australian J. Animal Sci., 3(4): 287-292.

Hadi, M. A. 1965. A preliminary study of certain productive and reproductive characters of marathwada buffaloes of Maharashtra state. Indian Vet. J., 42(9): 692-699.

Janakirman, K. 1982. Certain aspects of puberty, pregnancy and post-partum in water buffalo. Buffalo Bulletin, 1(1): 8.

Joshi, S. C., Tomar, S. P. S. and Desai, R. N. 1968. Relative importance of maternal and environmental influences on pregnancy in buffaloes on military farm in the north India. J. Dairy Sci., 21(1): 37-42.

Khan, S., Qureshi, M. S., Ahmad, N., Amjed, M., Durrani, F. R. and Younas, M. 2008. Effect of Pregnancy on Lactation Milk Value in Dairy Buffaloes. Asian Aust. J. Anim. Sci., 21(4): 523531.

Liu, C. H., Chang, S. H. and Huang, H. P. 1985. The Chinese indigenous buffaloes and its crossbreeding. Buffalo J., 1(1): 9-18.

Parera, B. M. A. O., Silva, L. N. A. D., Kuruwita, V. Y. and Karunaratae, A. M. 1987. Post partum ovarian activity, uterine involution and fertility in indigenous buffaloes at a selected village location in Srilanka. Ani. Repro.Sci., 14(2): 115-127.

Pervez, A., Aftab, M. K, Jaheer, A. and Hayat, S. H. 1994. Inheritance of some reproductive traits in Nili-Ravi buffaloes. Buffalo Bulletin, 13(1): 13-17.

Rao, B. R., Patel, V. G. and Tahman, S. S. 1973. Seasonal trend in reproductive behavior of surti buffaloes service period post-partum estrus interval. Indian Vet J., 50(5): 413-417.

Shabade, N. S., Jagtap, D. Z. and Behle, N. D. 1993. Factors affecting production and production efficiency traits of first lactation Murrah buffaloes. Indian J. Ani. Sci., 63(11): 1212-1213.

Shah, S. K. R., Mir, F. A. and Usmani, R. H. I. 1987. The performance of rural Nili-Ravi buffaloes (Bubalus bubalis) V. Gestation length. Indian J. Ani. Prod., 4(2): 88-90.

Suhail, S. M., Qureshi, M. S., Khan, S., Ihsanullah and Durrani, F. R. 2009. Inheritance of economic traits of dairy buffaloes in Pakistan. Sarhad J. Agric., 25(1): 87-93.

Tailor, S. P., Banarjee, A. K., Bachchu, S. and Pathodiya, O. P. 1997. Factors affecting post partum reproductive performance in Surti buffaloes. Indian J. Dairy Sci., 50(5): 407-409. 